\title{
Early changes in arbuscular mycorrhiza development in sugarcane under two harvest management systems
}

\author{
Lucas Carvalho Basilio de Azevedo ${ }^{1,3}$, Sidney Luiz Stürmer ${ }^{2}$, \\ Marcio Rodrigues Lambais ${ }^{1}$ \\ ${ }^{1}$ Departamento de Ciência do Solo, Escola Superior de Agricultura "Luiz de Queiroz", \\ Universidade de São Paulo, Piracicaba, SP, Brazil. \\ ${ }^{2}$ Departamento de Ciências Naturais, Universidade Regional de Blumenau, Blumenau, SC, Brazil. \\ ${ }^{3}$ Instituto de Ciências Agrárias, Universidade Federal de Uberlândia, Uberlândia, MG, Brazil.
}

Submitted: September 4, 2013; Approved: March 14, 2014.

\begin{abstract}
Sugarcane (Saccharum spp.) is grown on over 8 million ha in Brazil and is used to produce ethanol and sugar. Some sugarcane fields are burned to facilitate harvesting, which can affect the soil microbial community. However, whether sugarcane pre-harvest burning affects the community of arbuscular mycorrhizal fungi (AMF) and symbioses development is not known. In this study, we investigated the early impacts of harvest management on AMF spore communities and root colonization in three sugarcane varieties, under two harvest management systems (no-burning and pre-harvest burning). Soil and root samples were collected in the field after the first harvest of sugarcane varieties SP813250, SP801842, and RB72454, and AMF species were identified based on spore morphology. Diversity indices were determined based on spore populations and root colonization determined as an indicator of symbioses development. Based on the diversity indices, spore number and species occurrence in soil, no significant differences were observed among the AMF communities, regardless of harvest management type, sugarcane variety or interactions between harvest management type and sugarcane variety. However, mycorrhiza development was stimulated in sugarcane under the no-burning management system. Our data suggest that the sugarcane harvest management system may cause early changes in arbuscular mycorrhiza development.
\end{abstract}

Key words: glomeromycota, slash-and-burn, sugarcane harvest management, no-burning.

\section{Introduction}

Sugarcane (Saccharum spp.) is an economically and ecologically important crop in Brazil, covering $8.5 \times 10^{6}$ ha (CONAB, 2012) and yielding $23 \times 10^{9} \mathrm{~L}$ of ethanol and 39 x $10^{6}$ tons of sugar (2012/2013). During the last few years, sugarcane cultivation has spread into new areas due to the increased demand for ethanol, despite the potential environmental problems related to agricultural practices. It is still very common in Brazil the use of pre-harvesting burning to facilitate manual harvesting, since it eliminates straw and leaves while preserving stems intact. However, this practice increases air pollution and greenhouse gas emissions (Crutzen and Andreae, 1990; Fearnside, 2000), and estimulates constant debate on whether alternative practices should be used instead. As a consequence, policies to promote no-burning harvesting practices and reduce environmental impacts have been established and motivated studies on the effects of harvesting practices on plant productivity, nutrient use efficiency, and nitrogen fixation, for instance (Beary et al., 2002; Galdos et al., 2010; Macedo et al., 2008; Panosso et al., 2011). In addition, the residual lignocellulosic biomass produced by no-burning practices could be used as substrate for second-generation ethanol production (Silva et al., 2010; Soccol et al., 2010). Even though several studies have been performed in order to understand the effects of harvesting practices on plant and soil attributes, their effects on the microbial community of the

Send correspondence to M.R. Lambais. Departamento de Ciência do Solo, Escola Superior de Agricultura “Luiz de Queiroz", Universidade de São Paulo, Piracicaba, SP, Brazil. E-mail: mlambais@usp.br. 
soil and symbioses are mostly unknown. It has been shown that the use of pre-harvest burning can affect the soil organic matter (Canellas et al., 2010; Knicker, 2007; Rumpel et al., 2006) and the communities of soil microorganisms (Bastias et al., 2009; Jiménez-Esquilín et al., 2007; Otsuka et al., 2008). However, there is a lack of information regarding the community of arbuscular mycorrhizal fungi (AMF) and arbuscular mycorrhiza (AM) development in sugarcane under different harvest management systems.

Sugarcane is known to develop endomycorrhizal symbiosis with several species of AMF (Nasim et al., 2008; Reis et al., 2009). In AM, the fungi obtain carbohydrates from the plant for vegetative growth and spore production while enhancing plant mineral and water uptake (Smith and Read, 2008). AM play important roles in natural and agroecosystems by affecting soil structure, phosphorus uptake and, ultimately, plant community structure (van der Heijden et al., 1998; Rillig and Mummey, 2006; Wilson et al., 2009).

Studies on the interactions between sugarcane and AMF have been carried out in several countries. In Pakistan, Nasim et al. (2008) found that the number of spores of three Glomus species was increased during a single growing season and that low AMF root colonization was concurrent with severe red rot disease. In Iran, Rokni et al. (2010) surveyed fungal species diversity in 60 sugarcane fields and identified 10 species in four genera of AMF. In India, Srikumar et al. (2009) observed 11 AMF species associated with sugarcane, whereas Sivakumar (2012) identified 23 AMF species and observed that root colonization ranged from 60 to $89 \%$ in 14 sugarcane fields. In Brazil, Reis et al. (2009) observed that the level of mycorrhizal colonization was influenced by sugarcane variety and herbicide type, whereas Ambrosano et al. (2010) reported a positive correlation between mycorrhizal colonization of previous rotational crops and subsequent sugarcane height. Reis et al. (1999) studied 14 sugarcane varieties in three geographical regions of Brazil and observed higher AMF species richness and spore abundance in fields under no-burning harvesting, as compared to pre-harvesting burning. However, it is difficult to determine whether these differences were due to distinct harvesting management practices or different land use histories.

The hypothesis that burning of straw or vegetative matter may affect the communities of AMF has already been evaluated in several instances (Aguilar-Fernández et al., 2009; Bentivenga and Hetrick, 1991; Eom et al., 1999; Gibson and Hetrick, 1988; Haskins and Gehring, 2004; Korb et al., 2004), and some studies have shown that burning has limited effects on AMF communities. In a tall-grass prairie in Kansas (USA), Gibson and Hetrick (1988) found that Glomus fasciculatum was the only species influenced by burning, when compared to annually and infrequently burned sites. In Mexico, minor changes in AMF richness, spore abundance and root colonization were observed after the slash-and-burn conversion of a tropical dry forest into pasture (Aguilar-Fernández et al., 2009). Conversely, O'dea (2007) described lower levels of root colonization after burning in a semiarid grassland soil (Arizona, USA). Similarly, Korb et al. (2004) reported that mycorrhizal colonization of a bait corn plant was lower inside burned slash pile scars (pine forest) than outside.

The no-burning practices contribute to the input of organic matter to the soil after each annual harvest (Galdos et al., 2009), whereas burning could affect the mycorrhizal status (Eom et al., 1999; Klopatek et al., 1988). The accumulation of crop residues on the soil surface initially results in a layer of protective organic material, which decreases the variation in soil temperature and maintains higher soil humidity, as compared to systems that do not produce residues (Dourado-Neto et al., 1999; Tominaga et al., 2002). Higher levels of crop residues on the soil result also in a greater storage and release of plant nutrients over time, as well as changes to the physical attributes of the soil (Blair, 2000; Machado et al., 2010). Thus, the impact of crop residue deposition on soil temperature, humidity, nutrient availability and physical attributes of the soil may interdependently affect plant physiology and the development of symbioses, such as AM. Consequently, harvest management practices may be important determinants of arbuscular mycorrhiza development in sugarcane crops. However, whether harvest practices have early effects on the communities of AMF and symbioses development in sugarcane is not completely understood.

In this study, we evaluate whether there were early changes in the community of AMF and symbioses development after the first harvest of sugarcane with no pre-harvest burning, as compared to traditional systems using pre-harvest burning. Considering that the crop residues on the soil surface may promote higher soil humidity than burned controls (Dourado-Neto et al., 1999; Tominaga et al., 2002), and that soil humidity can be positively correlated with root colonization (Lingfei et al., 2005; Shukla et al., 2012) and AMF richness (Beauchamp et al., 2006; König et al., 2010), we hypothesized that no pre-harvesting burning in sugarcane fields increases AMF species richness and symbioses development even at the first harvest, if compared to a pre-harvesting burning controls.

\section{Material and Methods}

\section{Experimental site}

Soil samples were collected at an experimental area at Novo Horizonte, São Paulo, Brazil, located at 21 31 '10" S; $49^{\circ} 13^{\prime} 16^{\prime \prime} \mathrm{W}$, and at $440 \mathrm{~m}$ of altitude. The soil is a Typic Eutrustox and the climate is Aw, according to the Köppen classification, with dry winters and rainy summers. Average annual precipitation is $1349 \mathrm{~mm}$ and average annual temperature is $23.3^{\circ} \mathrm{C}$. At the sampling time, the accumulated precipitation for the last 12 months was $1140 \mathrm{~mm}$. 
The area is situated inside the largest contiguous sugarcane cropping region in Brazil. Site history included ten sugarcane crop cycles with pre-harvest burning followed by a single soybean crop.

We evaluated samples from soil and roots under three sugarcane varieties (SP813250, SP801842 and RB72454) harvested according to two management systems, i.e. with and without pre-harvest burning. Sugarcane varieties were planted spaced $1.5 \mathrm{~m}$ between rows, using a strip-plot design to efficiently apply harvest treatments that require agricultural traffic and fire control. Two strips containing three random plots of $15 \mathrm{~m} \times 6 \mathrm{~m}$ for each variety were established in the field. Each strip was harvested according to the harvesting management system. Sugarcane was harvested from both management areas using a sugarcane harvester. 84 days after the first harvest, after the sugarcane had sprouted and during tillering and rooting, two soil and root samples (from six random subsamples at depth 0-10 $\mathrm{cm}$ ) were obtained from each plot. Sugarcane yield after the first harvest was determined in tons of stems per hectare.

\section{Soil chemical analysis}

Soil $\mathrm{pH}$, levels of $\mathrm{H}+\mathrm{Al}, \mathrm{Al}, \mathrm{Ca}, \mathrm{Mg}, \mathrm{P}$ and total organic carbon content (TOC) were determined according to Raij et al. (2001). K was measured following the methods of EMBRAPA (1999). Cation exchange capacity (CEC), base $(\mathrm{Ca}+\mathrm{Mg}+\mathrm{K})$ saturation of $\mathrm{CEC}$ and $\mathrm{Ca}, \mathrm{Mg}$ and $\mathrm{K}$ saturation of CEC were calculated.

\section{Arbuscular mycorrhizal fungi in soil}

AMF spores were extracted from $50 \mathrm{~g}$ of soil by wet sieving (Gerdemann and Nicolson, 1963) and centrifugation in water, and in a $70 \%$ sucrose solution. The spores were rinsed with tap water and collected with a $38 \mu \mathrm{m}$ sieve. Spores were counted under a dissecting microscope and mounted on slides using polyvinyl-lacto-glycerol (PVLG) and PVLG with Melzer's reagent (1:1, v/v) for identification. AMF species were identified according to Schenck and Pérez (1990), and using morphological descriptions from the INVAM website (http://invam.cav.wvu.edu) and Glomeromycota species list website (http://www.lrz.de/ schuessler/amphylo/). Classification of AMF followed that of Redecker et al. (2013). Frequency of occurrence was calculated as the percentage of samples in which a particular species was detected. The Shannon diversity index and the reciprocal of the Simpson's index were calculated based on AMF spore abundance. Estimates of total species richness and sample coverage were based on the number of species detected in each treatment and computed using the SPADE program (Chao and Shen, 2003). Richness was estimated by ACE (Chao and Lee, 1992) and CHAO-1 methods (Chao, 1984). Pielou's index of equitability was calculated as described by Magurran (1988).

\section{Root colonization}

Roots were randomly separated using tweezers $(1 \mathrm{~g}$ from each sample), rinsed in tap water to eliminate soil debris, immersed for $15 \mathrm{~h}$ in $10 \% \mathrm{KOH}$ solution at room temperature and then placed in a water bath at $60^{\circ} \mathrm{C}$ for $10 \mathrm{~min}$ for clarification. Afterwards, the $\mathrm{KOH}$ solution was discarded, roots were washed with tap water and immersed in a staining solution (5\% Parker blue pen ink, $5 \%$ acetic acid and $10 \%$ lactic-glycerol for $3 \mathrm{~min}$ at $90{ }^{\circ} \mathrm{C}$ (Vierheilig et al., 1998). Mycorrhizal root colonization was measured under a dissecting microscope using the grid-line intersect method of Giovannetti and Mosse (1980).

\section{Statistical analysis}

The GLIMMIX procedure from SAS 9.2 (Littell et $a l ., 2006)$ was used to test the effects of harvesting management, sugarcane varieties, and harvesting management and sugarcane variety interactions. Means were compared using the Tukey-Kramer test $(\mathrm{p}<0.05)$. For normalization, spore counts were transformed to $(\mathrm{x}+0.5)^{0.5}$ and root colonization data were transformed to $\arcsin (\mathrm{x}+1)^{0.5}$. Correlations between root colonization and spore number in the soil were measured by Pearson's correlation analysis.

Redundancy Analysis (RDA) was performed using Canoco for Windows software to determine the relationships between AMF occurrence data and environmental variables (root colonization level and soil attributes). Variables were chosen by forward selection associated with the Monte Carlo permutation test to better explain data variability and determine significant data ordination.

\section{Results}

\section{Chemical attributes and sugarcane yield}

Most of soil chemical attributes did not present significant differences among treatments, with means as following: $\mathrm{pH}$ : 5.9 (5.7 to 6.0$)$; $\mathrm{H}+\mathrm{Al}: 12.5 \mathrm{mmol}_{\mathrm{c}} \mathrm{kg}^{-1}$ (11.7 to 13.0); Ca: 18.4 mmol $_{\mathrm{c}} \mathrm{kg}^{-1}$ (16.8 to19.7); $\mathrm{K}: 4.0 \mathrm{mmol}_{\mathrm{c}} \mathrm{kg}^{-1}$ (3.7 to 4.5); P: $12.9 \mathrm{mg} \mathrm{kg}^{-1}$ (11.2 to 14.5); CEC: $42.5 \mathrm{mmol}_{\mathrm{c}} \mathrm{kg}^{-1}$ (40.8 to 44.2 ); and base saturation: $70.2 \%$ (68.1 to 72.2). Soil chemical attributes with significant differences are shown in Table 1. Soil Mg content and Mg saturation were higher $(\mathrm{p}=0.0498$ and $\mathrm{p}=0.0311$, respectively) under pre-harvest burning than under no-burning management for variety SP813250 (Table 1). Conversely, $\mathrm{Mg}$ saturation was higher under no-burning conditions than under burning conditions for SP801842 ( $p$ $=0.0064) \mathrm{Mg}$ saturation was also higher for variety SP801842 than SP813250 under no-burning management $(\mathrm{p}=0.0142)$. Total organic carbon content (TOC) was higher $(\mathrm{p}=0.0162)$ under burning than under no-burning management for SP801842. TOC was higher for RB72454 than for SP801842 under no-burning management $(\mathrm{p}=$ 0.0496). Al was not detected in any of the treatments (possibly due to Al precipitation at $\sim \mathrm{pH} 6.0$ ). Sugarcane yield 
Table 1 - Chemical attributes of soil cultivated with different sugarcane varieties (SP813250, SP801842 and RB72454), under no-burning and pre-harvest burning managements.

\begin{tabular}{|c|c|c|c|c|c|}
\hline \multirow[t]{2}{*}{ Attribute } & \multirow[t]{2}{*}{ Harvest management $(\mathrm{HM})$} & \multirow[t]{2}{*}{ HM average } & \multicolumn{3}{|c|}{ Variety } \\
\hline & & & SP813250 & SP801842 & RB72454 \\
\hline \multirow[t]{2}{*}{$\mathrm{Mg}\left(\mathrm{mmol}_{\mathrm{c}} \mathrm{kg}^{-1}\right)$} & UNB & $7.6 \pm 0.73 \mathrm{~A}$ & $7.0 \pm 0.50 \mathrm{Ba}$ & $7.8 \pm 0.29 \mathrm{Aa}$ & $7.8 \pm 1.04 \mathrm{Aa}$ \\
\hline & BUR & $7.5 \pm 0.71 \mathrm{~A}$ & $7.7 \pm 0.76 \mathrm{Aa}$ & $7.5 \pm 0.50 \mathrm{Aa}$ & $7.3 \pm 1.04 \mathrm{Aa}$ \\
\hline \multirow[t]{2}{*}{ Organic $\mathrm{C}\left(\mathrm{g} \mathrm{kg}^{-1}\right)$} & UNB & $8.6 \pm 1.60 \mathrm{~A}$ & $9.1 \pm 0.44 \mathrm{Ab}$ & $7.4 \pm 1.86 \mathrm{Bb}$ & $9.4 \pm 1.70 \mathrm{Aa}$ \\
\hline & BUR & $9.1 \pm 0.99 \mathrm{~A}$ & $8.3 \pm 0.17 \mathrm{Aa}$ & $9.9 \pm 0.60 \mathrm{Aa}$ & $8.9 \pm 1.21 \mathrm{Aa}$ \\
\hline \multirow[t]{2}{*}{ Mg saturation (\%) } & UNB & $17.8 \pm 1.39 \mathrm{~A}$ & $16.7 \pm 1.39 \mathrm{Bb}$ & $18.9 \pm 0.92 \mathrm{Aa}$ & $17.8 \pm 1.03 \mathrm{Aab}$ \\
\hline & BUR & $17.6 \pm 0.91 \mathrm{~A}$ & $18.0 \pm 0.07 \mathrm{Aa}$ & $17.0 \pm 0.93 \mathrm{Ba}$ & $17.9 \pm 1.23 \mathrm{Aa}$ \\
\hline
\end{tabular}

HM average values are average \pm standard deviation $(n=9)$. Variety values are average \pm standard deviation $(n=3)$. Upper case letters compare the two harvest managements (UNB, no burning; BUR, burning). Lower case letters within a row compare the interaction between harvest management and variety treatments. Values followed by different letters are significantly different (Tukey-Kramer test, $\mathrm{p}<0.05$ ).

was not affected by variety or harvesting management practice, with a mean value of 127.4 ton $\mathrm{ha}^{-1}(\mathrm{SE}=8.3, \mathrm{n}=$ 3).

\section{Arbuscular mycorrhizal fungi community in the soil}

Average AMF spore abundance ranged from 31 to 40 in $50 \mathrm{~g}$ of soil for each treatment, with an overall mean of 36.7 per $50 \mathrm{~g}$ of soil. However, the differences between harvesting management practices $(p=0.83)$ or varieties $(p=$ 0.53 ) were not significant.

A total of 37 AMF species (morphotypes) were detected associated with sugarcane. However, 21 morphotypes were identified only at genus level, since they could not be assigned to known species. Twenty-two species were common to both management types, 9 species were exclusively detected under no-burning management, and 6 species were exclusively detected under pre-harvest burning management (Table 2). These species were assigned to the genera Acaulospora, Archaeospora, Rhizophagus, Glomus, Funneliformis, Paraglomus, Gigaspora, Scutellospora, and Racocetra (Figure 1). The most frequent species (> 50\%) were Acaulospora morrowiae, A. scrobiculata, Glomus sp. 1, Glomus sp. 6, G. macrocarpum, and S. pellucida (Table 2). The highest spore abundances were observed for these same species: Glomus sp. 6 (217 spores), Glomus sp.1 (150), Glomus macrocarpum (125), S. pellucida (111), A. scrobiculata (80) and $A$. morrowiae (55). These six species accounted for $79.5 \%$ of the total spore population. Most of the species were detected in $<10 \%$ of the samples.

Some species were detected exclusively in samples from no-burning treatments, such as Acaulospora sp. 6, Acaulospora sp. 8, R. clarus, C. lamellosum, F. mosseae, G. tortuosum, Glomus sp. 10, Scutellospora sp. and $R$. verrucosa (Table 2). Conversely, Acaulospora sp. 2, Acaulospora sp. 5, Acaulospora sp. 7, Glomus sp. 8, Glomus sp. 9 and P. occultum spores were detected only in samples from the pre-harvesting burning treatment. How- ever, these species were detected at low abundance levels, and mostly represented by one spore per sample.

Based on AMF spores, species richness (number of AMF species observed), Shannon and Simpson diversity indices, evenness and estimation of total species richness (ACE and CHAO-1 method) did not differ statistically between varieties and harvesting management practices (Table 3 ). The number of identified species ranged from approximately 6 to 9 under each sugarcane variety within each harvest management practice. The estimated species number ranged from 6 to 20 (ACE-1 and CHAO-1). The average estimated sample coverage was $87 \%$, when using all samples for the estimations.

\section{Root colonization}

Mycorrhizal colonization was observed in all sugarcane roots, and averaged 30 to $52 \%$. Colonization levels were higher for all sugarcane varieties under no pre-harvest burning management $(\mathrm{p}=0.0053$ for SP813250; $\mathrm{p}=0.0058$ for SP801842; and $\mathrm{p}=0.0018$ for RB72454 variety) (Table 4).

\section{Relatioships between AMF community, root colonization and soil attributes}

RDA was applied to the AMF species, root colonization, and soil attributes under each sugarcane variety to better understand their relationships. The first axis explained $25.3 \%$ to $28.3 \%$, and the second $14.0 \%$ to $18.2 \%$ of the data variability within each sugarcane variety treatment (Figure $2 \mathrm{a}, \mathrm{b}$ and $\mathrm{c}$ ). Together, the first two axes explained $42.4 \%, 43.5 \%$ and $44.1 \%$ of the data variability for RB72454, SP813250 and SP801842 variety, respectively. Harvest management type and the variables chosen by forward selection significantly explained data variability within sugarcane varieties, according to the Monte Carlo permutation test ( $\mathrm{p}=0.01$ to 0.038 for the first canonical axis and 0.012 to 0.044 for the sum of all canonical axes). On the other hand, RDA did not show grouping of samples by harvest management, suggesting that pre-harvest burn- 
Table 2 - Abundance of arbuscular mycorrhizal fungi (AMF) spores and frequency of occurrence in soil samples under three sugarcane varieties (SP813250, SP801842 and RB72454) and harvesting with no-burning (UNB) and pre-harvesting burning (BUR) management.

\begin{tabular}{|c|c|c|c|c|c|c|c|}
\hline \multirow[b]{2}{*}{ Family/Species } & \multicolumn{3}{|c|}{ UNB } & \multicolumn{3}{|c|}{ BUR } & \multirow{2}{*}{$\begin{array}{l}\text { Frequency } \\
\text { of occur- } \\
\text { rence (\%) }\end{array}$} \\
\hline & SP813250 & SP801842 & RB72454 & SP813258 & SP801842 & RB72454 & \\
\hline \multicolumn{8}{|l|}{ Archaeosporaceae } \\
\hline $\begin{array}{l}\text { Archaeospora trappei (Ames \& Linderman) Morton \& } \\
\text { Redecker }\end{array}$ & - & 2 & 2 & - & 1 & - & 9.7 \\
\hline \multicolumn{8}{|l|}{ Paraglomeraceae } \\
\hline Paraglomus laccatum (Blaszk.) Renker, Blaszk. \& Buscot & - & 1 & 2 & - & 3 & 4 & 22.6 \\
\hline Paraglomus occultum (Walker) Morton \& Redecker & - & - & - & 1 & - & - & 3.2 \\
\hline \multicolumn{8}{|l|}{ Glomeraceae } \\
\hline Rhizophagus clarus (Nicol. \& Schenck) Walker \& Schussler & 1 & - & - & - & - & - & 3.2 \\
\hline Funneliformis mosseae (Nicol \& Gerd.) Walker \& Schussler & - & 1 & - & - & - & - & 3.2 \\
\hline Glomus coremioides (Berk. \& Broome) Redecker \& Morton & - & $2^{\mathrm{a}}$ & - & $2^{\mathrm{a}}$ & - & $1^{\mathrm{a}}$ & 9.7 \\
\hline Glomus macrocarpum Tulasne \& Tulasne & 13 & 4 & 40 & 16 & 36 & 16 & 54.8 \\
\hline Glomus sinuosum (Gerd. \& Bakshi) Almeida \& Schenck & $2^{\mathrm{a}}$ & - & - & $3^{\mathrm{a}}$ & - & $1^{\mathrm{a}}$ & 12.9 \\
\hline Glomus tortuosum Schenck \& Smith & 1 & - & - & - & - & - & 3.2 \\
\hline Glomus viscosum cf $\mathrm{Nicol}$. & - & - & 1 & 1 & 2 & - & 9.7 \\
\hline Glomus sp. 1 & 21 & 43 & 7 & 44 & 27 & 8 & 67.7 \\
\hline Glomus sp. 2 & 1 & 6 & 2 & 2 & 2 & - & 22.6 \\
\hline Glomus sp. 3 & 5 & 1 & - & 1 & - & - & 12.9 \\
\hline Glomus sp. 4 & 3 & 3 & 4 & 2 & 3 & 1 & 22.6 \\
\hline Glomus sp. 5 & 5 & 4 & 1 & - & 2 & - & 12.9 \\
\hline Glomus sp. 6 & 47 & 37 & 17 & 44 & 35 & 37 & 67.7 \\
\hline Glomus sp. 7 & - & - & 8 & 3 & - & - & 9.7 \\
\hline Glomus sp. 8 & - & - & - & - & 3 & - & 3.2 \\
\hline Glomus sp. 9 & - & - & - & 1 & - & - & 3.2 \\
\hline Glomus sp. 10 & 1 & - & - & - & - & - & 3.2 \\
\hline Glomus sp. 11 & 2 & 1 & - & - & 4 & 1 & 12.9 \\
\hline \multicolumn{8}{|l|}{ Claroideoglomeraceae } \\
\hline $\begin{array}{l}\text { Claroideoglomus lamellosum (Dalpe, Koske \& Tews) Walker } \\
\& \text { Schussler }\end{array}$ & - & - & 1 & - & - & - & 3.2 \\
\hline \multicolumn{8}{|l|}{ Acaulosporaceae } \\
\hline Acaulospora mellea Spain \& Schenck & 4 & 6 & 2 & 4 & 1 & 21 & 41.9 \\
\hline Acaulospora morrowiae Spain \& Schenck & 2 & 12 & 6 & 14 & 13 & 8 & 64.5 \\
\hline Acaulospora scrobiculata Trappe & 33 & 9 & 6 & 26 & 2 & 4 & 54.8 \\
\hline Acaulospora sp. 1 & 2 & 1 & - & - & 8 & 2 & 19.4 \\
\hline Acaulospora sp. 2 & - & - & - & - & 2 & - & 3.2 \\
\hline Acaulospora sp. 3 & - & 1 & 2 & - & 1 & - & 9.7 \\
\hline Acaulospora sp. 4 & - & 2 & 2 & 2 & - & - & 9.7 \\
\hline Acaulospora sp. 5 & - & - & - & - & 1 & - & 3.2 \\
\hline Acaulospora sp. 6 & - & - & 1 & - & - & - & 3.2 \\
\hline Acaulospora sp. 7 & - & - & - & - & 1 & 1 & 6.5 \\
\hline Acaulospora sp. 8 & - & 1 & - & - & - & - & 3.2 \\
\hline \multicolumn{8}{|l|}{ Gigasporaceae } \\
\hline Gigaspora sp. & 1 & 2 & 1 & 4 & 4 & 1 & 35.5 \\
\hline Scutellospora pellucida (Nicol. \& Schenck) Walker \& Sanders & 20 & 20 & 2 & 28 & 17 & 24 & 67.7 \\
\hline Scutellospora sp. & - & 1 & - & - & - & - & 3.2 \\
\hline $\begin{array}{l}\text { Racocetra verrucosa (Koske \& Walker) Oehl, Souza \& } \\
\text { Sieverd. }\end{array}$ & 1 & - & - & - & - & - & 3.2 \\
\hline
\end{tabular}

\footnotetext{
a - Number of sporocarps.
} 


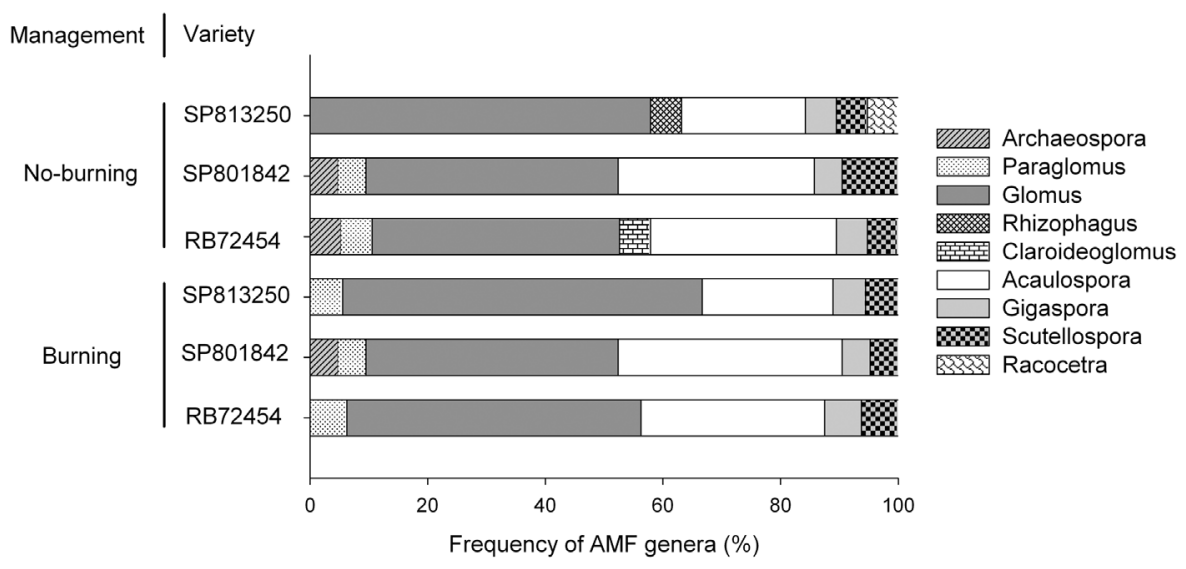

Figure 1 - Relative frequency of arbuscular mycorrhizal fungi genera, based on number of species detected in soil under three sugarcane varieties (SP813250, SP801842 and RB72454) and under harvesting with no-burning and pre-harvest burning managements.

Table 3 - AMF Species richness, estimated species richness, diversity index and sample coverage based on spore morphotypes from soil under sugarcane varieties SP813250, SP801842 and RB72454, harvested with no-burning or pre-harvest burning managements.

\begin{tabular}{|c|c|c|c|c|c|}
\hline \multirow[t]{2}{*}{ Attribute } & \multirow[t]{2}{*}{ Harvest management (HM) } & \multirow[t]{2}{*}{ HM average } & \multicolumn{3}{|c|}{ Variety } \\
\hline & & & SP813250 & SP801842 & RB72454 \\
\hline \multirow[t]{2}{*}{$\mathrm{S}_{\mathrm{AMF}}^{\mathrm{a}}$} & UNB & $6.50 \pm 1.70$ & $6.17 \pm 2.26$ & $7.83 \pm 0.58$ & $5.50 \pm 1.32$ \\
\hline & BUR & $7.44 \pm 1.53$ & $8.00 \pm 0.00$ & $7.00 \pm 2.29$ & $7.33 \pm 2.52$ \\
\hline \multirow[t]{2}{*}{ Shannon $^{\mathrm{b}}$} & UNB & $1.50 \pm 0.28$ & $1.38 \pm 0.25$ & $1.71 \pm 0.13$ & $1.42 \pm 0.38$ \\
\hline & BUR & $1.57 \pm 0.22$ & $1.66 \pm 0.19$ & $1.59 \pm 0.20$ & $1.47 \pm 0.16$ \\
\hline \multirow[t]{2}{*}{$1 / D^{b, c}$} & UNB & $3.93 \pm 0.95$ & $3.40 \pm 0.48$ & $4.59 \pm 0.60$ & $3.79 \pm 1.39$ \\
\hline & BUR & $4.02 \pm 1.00$ & $4.50 \pm 1.12$ & $4.15 \pm 0.26$ & $3.40 \pm 0.33$ \\
\hline \multirow[t]{2}{*}{ Evenness $^{\mathrm{d}}$} & UNB & $0.82 \pm 0.08$ & $0.79 \pm 0.02$ & $0.83 \pm 0.03$ & $0.84 \pm 0.14$ \\
\hline & BUR & $0.81 \pm 0.07$ & $0.81 \pm 0.11$ & $0.84 \pm 0.05$ & $0.78 \pm 0.08$ \\
\hline \multirow[t]{2}{*}{$\mathrm{ACE}-1^{\mathrm{e}}$} & UNB & $10.05 \pm 4.24$ & $10.52 \pm 6.00$ & $13.13 \pm 0.49$ & $6.5 \pm 1.45$ \\
\hline & BUR & $15.47 \pm 9.87$ & $13.45 \pm 4.56$ & $10.10 \pm 15.9$ & $22.85 \pm 14.8$ \\
\hline \multirow[t]{2}{*}{$\mathrm{Chao}^{\mathrm{e}}$} & UNB & $8.48 \pm 3.53$ & $8.63 \pm 5.49$ & $10.72 \pm 1.67$ & $6.10 \pm 1.25$ \\
\hline & BUR & $11.51 \pm 5.37$ & $11.27 \pm 1.18$ & $8.22 \pm 9.97$ & $15.05 \pm 8.76$ \\
\hline \multirow[t]{2}{*}{$\mathrm{ESC}^{\mathrm{f}}$} & UNB & $0.89 \pm 0.06$ & $0.90 \pm 0.06$ & $0.88 \pm 0.01$ & $0.89 \pm 0.09$ \\
\hline & BUR & $0.84 \pm 0.16$ & $0.91 \pm 0.01$ & $0.93 \pm 0.08$ & $0.70 \pm 0.20$ \\
\hline
\end{tabular}

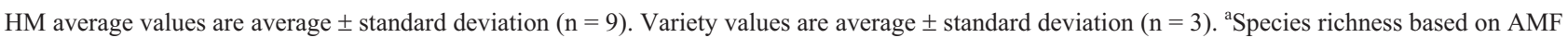
spores; ${ }^{b}$ Shannon index based on maximum likelihood estimator; ${ }^{\circ}$ Reciprocal of Simpson's index; ${ }^{\mathrm{d}}$ Pielou's Evenness index; ${ }^{\mathrm{e}}$ Non-parametric stimator of species richness; ${ }^{\mathrm{f}}$ Estimated sample coverage. Means do not differ statistically (Tukey-Kramer test, $\mathrm{p}<0.05$ ).

Table 4 - AM fungal colonization (\%) of roots of three sugarcane varieties under harvesting with no-burning or pre-harvest burning managements.

\begin{tabular}{lcc}
\hline & \multicolumn{2}{c}{ Management } \\
Variety & No-burning & Burning \\
\hline SP813250 & $51.87 \pm 3.04 \mathrm{aA}$ & $36.23 \pm 2.87 \mathrm{aB}$ \\
SP801842 & $45.20 \pm 9.46 \mathrm{aA}$ & $30.10 \pm 2.29 \mathrm{aB}$ \\
RB72454 & $49.33 \pm 4.29 \mathrm{aA}$ & $31.24 \pm 9.58 \mathrm{aB}$ \\
\hline
\end{tabular}

Values are average \pm standard deviation $(n=3)$. Means followed by the same lower case letter in a column and upper case letter in a row do not differ statistically (Tukey-Kramer test, $\mathrm{p}<0.05$ ). ing had no effect on the AMF spore community after the first sugarcane harvest.

The attributes that best explained the variability in the SP813250 RDA data were total organic carbon (TOC), P level, $\mathrm{K}$ saturation, $\mathrm{H}+\mathrm{Al}$ level and root colonization (Figure 2a). According to the RDA, P levels in the soil correlated positively with root colonization, even though there were no differences in $\mathrm{P}$ content among treatments. Most of the AMF species correlated with the $\mathrm{H}+\mathrm{Al}$ levels in the soil and a few of the species correlated with TOC, K saturation and colonization levels. RDA ordination of the SP801842 data showed no species distribution patterns (Figure 2b). $\mathrm{CEC}$ saturation in $\mathrm{Ca}, \mathrm{Mg}, \mathrm{K}, \mathrm{H}+\mathrm{Al}$ level and root coloni- 

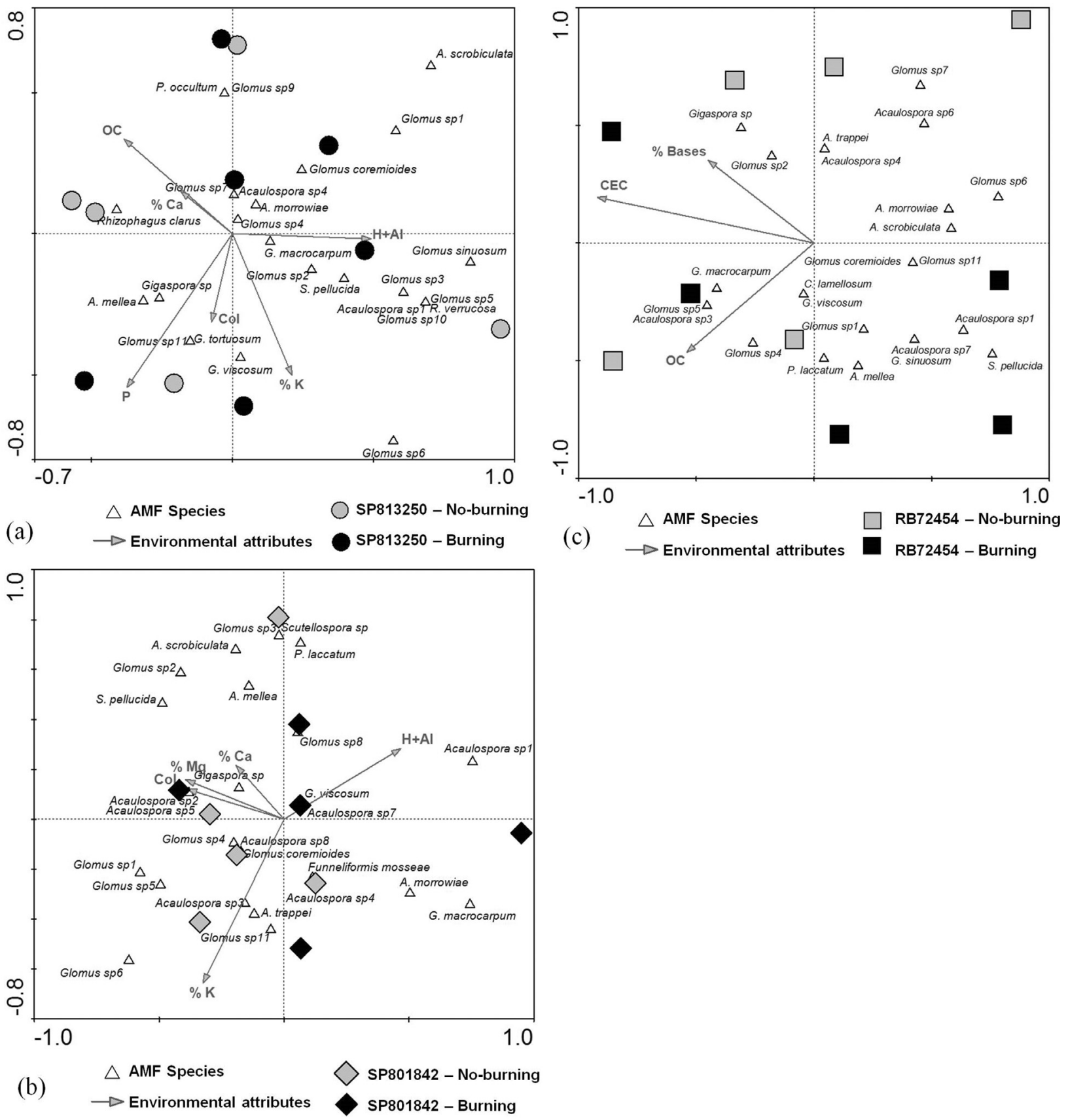

Figure 2 - Correlation triplot based on redundancy analysis (RDA) of arbuscular mycorrhizal fungal (AMF) spore, environmental attributes (soil chemical and AMF colonization) and sample in soil under sugarcane varieties SP813250 (a), SP801842 (b) and RB72454 (c), and under harvesting with no-burning and pre-harvest burning managements. The two first canonical axes are shown. Soil chemical attributes and AMF colonization were selected with forward selection to best explain the ordination data. According with Monte Carlo permutation test, $\mathrm{p}$ values are $<0.05$ for the first and the sum of all canonical axes in (a), (b) and (c) analysis. $\mathrm{OC}=$ organic carbon; $\mathrm{P}=$ phosphorus level; $\mathrm{Col}=$ root colonization level; $\mathrm{H}+\mathrm{Al}=\mathrm{H}+\mathrm{Al}$ level; $\mathrm{CEC}=$ cation exchangeable capacity; $\%$ Base $=$ base saturation of $\mathrm{CEC} ; \% \mathrm{Ca}, \% \mathrm{Mg}$ and $\% \mathrm{~K}=$ respectively calcium, magnesium and potassium saturation of CEC. Size and orientation of vectors and species represents correlation among them and with the axes.

zation best explained the data variability in the treatments under SP801842 variety. For treatments under variety RB72454, RDA analysis showed TOC, CEC and CEC base saturation as the soil attributes that best explained data variability (Figure 2c). Most of the AMF species were negatively correlated with these three attributes.

\section{Discussion}

In this study, as expected, we observed no difference in sugarcane yield between the two harvest management practices, given that pre-harvest burning takes place at the end of the sugarcane development cycle and consequently has little impact on sugarcane production at the first har- 
vest. However, no-burning harvesting management increases sugarcane production after a series of harvesting cycles (Resende et al., 2006) due to the longer term addition of organic matter and its effect on the soil structure and fertility.

After the first harvest, sugarcane harvest management had no markedly effect on soil chemical properties. Although the deposition of crop residues under no-burning harvest management increased (Galdos et al., 2010; Panosso et al., 2011), soil organic carbon levels did not differ between burned and unburned areas. The lack of variation in TOC in the soil under the different harvest management practices may be a result of the insufficient time for sugarcane straw to decompose and the resulting carbon to be incorporated in the soil under no-burning management.

None of the treatments had significant effect on AMF spore abundance either. Spore population ranged from 31 to 40 spores per $50 \mathrm{~g}$ of soil, which were in the low range of populations observed by Reis et al. (1999) (19 to 815 spores $50 \mathrm{~mL}^{-1}$ ), and Nasim et al. (2008) (more than 500 spores $10 \mathrm{~g}^{-1}$ ). AMF sporulation is partly host-dependent (Al-Raddad, 1995; Bever et al., 1996), and, therefore, differences between our results and the results of other studies can be attributed to distinct host genotypes and environmental factors.

In our study, the dominant AMF species in terms of abundance and frequency of occurrence in the soil were different from those reported for other sugarcane studies (Reis et al., 1999; Nasim et al., 2008; Srikumar et al., 2009). A1together, these results demonstrate the difficulty in predicting AMF community structure just based on plant host. Similar difficulties in predicting AMF community structure were observed for several ecosystems of Brazil (Stürmer and Siqueira, 2006). In general, the data on AMF spores abundance suggest that occurrence and dominance of AMF species are driven not only by intrinsic factors of the host plant and local soil, but also by historical factors, such as sugarcane land use history.

Despite the paucity of studies investigating AMF diversity and community structure in sugarcane plantations, the number of AMF species detected in our study (37) is high, considering that the experiment was carried out in a small area and only one geographical region. Numbers of AMF species associated with sugarcane range from 10 species, detected using trap plants in soils cultivated with four sugarcane varieties in Iran (Rokni et al., 2010), to 18 species in three different Brazilian fields with 14 sugarcane varieties (Reis et al., 1999), and 23 species in 14 sugarcane fields in India (Sivakumar, 2012). Given the known diversity of AMF in sugarcane fields, how in the current study can the relatively high AMF species richness, in a soil under over 10 cycles of sugarcane monoculture and just one cycle of soybean rotation be explained? The species richness per treatment (Table 3 ) is similar to the richness observed in other studies (Rokni et al., 2010). In addition, 9 and 6 AMF species were detected exclusively in the noburning and pre-harvest burning treatments, respectively, suggesting that local-scale factors, such as the interaction between sugarcane varieties and distinct soil chemical attributes, led to the high diversity of AMF spores in this small area of sugarcane. In addition, the rotation with soybean might also have contributed to the high diversity of AMF spores observed.

Indeed, results from the RDA showed that within each sugarcane variety, AMF species correlate with distinct soil attributes (Figure $2 \mathrm{a}, \mathrm{b}$ and c). Most of the AMF species abundance was positively related to $\mathrm{H}+\mathrm{Al}$ and negatively related to TOC in soil under variety SP813250, positively related to root colonization, $\mathrm{Ca}, \mathrm{Mg}$ and $\mathrm{K}$ saturation in soil under variety SP801842, and negatively related to base saturation, cation exchange capacity and TOC in soil under variety RB72454. These results suggest that soil chemical attributes play a significant role in determining the structure of AMF communities, based on spore morphotypes, in soils cultivated with different sugarcane varieties. Nevertheless, considering the variation observed, the predictability of AMF community structure based on soil chemical attributes is low after the first sugarcane harvest.

Despite the significant effect of soil chemical attributes on the explanation of AMF communities variability in the soil cultivated with the three sugarcane varieties, persistent correlations were not found among AMF species, environmental attributes and management systems (Figure 2). In addition, RDA did not reveal differences among treatments based on the number of spores from each species or community structure based on the presence or absence of species (data not shown), indicating that there are no changes in soil AMF communities after the first harvest of sugarcane without or with pre-harvest burning. Similarly, few alterations in AMF richness in a pasture established after the burning of a tropical forest were reported (AguilarFernandéz et al. (2009), suggesting that burning may not be a driver of the community of AMF, based on spores.

AMF colonization of sugarcane roots in the current study is within the range observed in other studies, i.e. 10 to $89 \%$ in sugarcane under different field and greenhouse conditions (Kelly et al., 2001; Reis et al., 2009; Sivakumar, 2012). However, no-burning management resulted in higher root colonization after the first harvest, as compared to pre-harvest burning management. Given that soil mechanical interference was homogenous in our experiment, and that root colonization can be positively correlated with soil humidity, this differences in root colonization observed in our study may possibly be due to the higher levels of humidity resulted from crop residue deposition on the soil surface after the harvest (He et al., 2002; Lingfei et al., 2005; Shukla et al., 2012). Alternatively, the lower levels of root colonization in the treatments with pre-harvest burning management may be explained by the negative effect of 
burning on AMF propagules in the soil, as observed in a semiarid grassland (O'dea, 2007) and in corn grown in soil from burned slash pile scars of a pine forest (Korb et al., 2004). Symbioses development can contribute to plant nutrition, mycelial growth through the soil and sporulation of the AMF, and, ultimately, AMF survival in the system. Therefore, our data suggest that no-burning harvest management is more prone to sustain the ecological roles of AM in the sugarcane fields.

In this study, we have shown that changing from a long-standing practice of pre-harvest sugarcane burning to a no-burning harvest management does not affect soil chemical attributes and AMF community (e.g. spore richness, frequency of common species, species richness, and diversity indices) after the first harvest. However, root colonization by AMF may benefit from no-burning practices since the very first sugarcane cultivation cycle. Therefore, root colonization is a sensitive indicator of environmental changes in sugarcane fields, since it represents the active growing phase of intraradical fungi. This study represents the first step towards understanding the effects of sugarcane harvesting management practices on AMF community and their functional roles in sugarcane fields. In addition, our data contribute to background information on the diversity of an important group of soil fungi and can be used to help in establishing sustainable management practices for important cash crops.

\section{Acknowledgments}

We thank the MSc. Rene de Assis Sordi (Grupo São Martinho, CTC), Dr. Carlos Suguitani (CTC) and Usina São José da Estiva for providing the experimental area and for measuring sugarcane yields in the field. LCBA was supported by CNPq (Brasília, Brazil) and the São Paulo Research Foundation (FAPESP). SLS and MRL were supported by CNPq (Brasília, Brazil). This project was partially funded by FAPESP and $\mathrm{CNPq}$ through grants to MRL.

\section{References}

Aguilar-Fernandéz M, Jaramillo VJ, Varela-Fregoso L, Gavito ME (2009) Short-term consequences of slash-and-burn practices on the arbuscular mycorrhizal fungi of a tropical dry forest. Mycorrhiza 19:179-186.

Al-Raddad AM (1995) Mass production of Glomus mosseae spores. Mycorrhiza 5:229-231.

Ambrosano EJ, Azcón R, Cantarella H, Ambrosano GMB, Schammass EA, Muraoka T, Trivelin PCO, Rossi F, Guirado N, Ungaro MRG, Teramoto JRS (2010) Crop rotation biomass and arbuscular mycorrhizal fungi effects on sugarcane. Sci Agric 67:692-701.

Bastias BA, Anderson IC, Rangel-Castro JI, Parkin PI, Prosser JI, Cairney JEG (2009) Influence of repeated prescribed burning on incorporation of ${ }^{13} \mathrm{C}$ from cellulose by forest soil fungi as determined by RNA stable isotope probing. Soil Biol Biochem 41:467-472.
Beary TP, Boopathy R, Templet P (2002) Accelerated decomposition of sugarcane crop residue using a fungal-bacterial consortium. Int Biodeterior Biodegrad 50:41-46.

Beauchamp VB, Stromberg JC, Stutz JC (2006) Arbuscular mycorrhizal fungi associated with Populus-Salix stands in a semiarid riparian ecosystem. New Phytol 170:369-380.

Bentivenga SP, Hetrick BAD (1991) Relationship between mycorrhizal activity, burning, and plant productivity in tallgrass prairie. Can J Bot 69:2597-2602.

Bever JD, Morton JBB, Antonovics J, Schultz PA (1996) Hostdependent sporulation and species diversity of arbuscular mycorrhizal fungi in a mown grassland. J Ecol 84:71-82.

Blair N (2000) Impact of cultivation and sugar-cane green trash management on carbon fractions and aggregate stability for a Chromic Luvisol in Queensland, Australia. Soil Tillage Res 55:183-191.

Canellas LP, Busato JG, Dobbss LB, Baldotto MA, Rumjanek VM, Olivares FL (2010) Soil organic matter and nutrient pools under long-term non-burning management of sugar cane. Eur J Soil Sci 61:375-383.

Chao A (1984) Nonparametric estimation of the number of classes in a population. Scan J Stat 11:265-270.

Chao A, Lee SM (1992) Estimating the number of classes via sample coverage. J Am Stat Assoc 87:210-217.

Chao A, Shen TJ. 2003. Program SPADE (Species Prediction And Diversity Estimation) - program and user's guide. Access under: Available at: http://chao.stat.nthu.edu.tw. Accessed 20 August 2013.

Companhia Nacional do Abastecimento - CONAB. 2012. Acompanhamento da Safra Brasileira - Cana-de-Açúcar. Brazilian Ministry of Agriculture. Available at: http://www.conab.gov.br. Accessed 15 October 152012.

Crutzen PJ, Andreae MO (1990) Biomass burning in the tropics: impact on atmospheric chemistry and biogeochemical cycles. Science 250:1669-1678.

Dourado-Neto D, Timm LC, Oliveira JCM, Reichardt K, Bacchi OOS, Tominaga TT, Cássaro FAM (1999) State-space approach for the analysis of soil water content and temperature in sugarcane crop. Sci Agric 56:1215-1221.

Empresa Brasileira de Pesquisa Agropecuária - EMBRAPA (1999) Manual de análises químicas de solos, plantas e fertilizantes. Embrapa, Rio de Janeiro, Brazil.

Eom A-H, Hartnett DC, Wilson GWT, Figge DAH (1999) The effect of fire, mowing and fertilizer amendment on arbuscular mycorrhizas in tallgrass prairie. Am Midl Nat 142:55-70.

Fearnside PM (2000) Global warming and tropical land-use change: greenhouse gas emission from biomass burning, decomposition and soils in forest conversion, shift cultivation and secondary vegetation. Clim Chang 46:115-158.

Galdos MV, Cerri CC, Cerri CEP (2009) Soil carbon stocks under burned and unburned sugarcane in Brazil. Geoderma 153:347-352.

Galdos MV, Cerri CC, Lal R, Bernoux M, Feigl BJ, Cerri CEP (2010) Net greenhouse gases fluxes in Brazilian ethanol production systems. GCB Bioenergy 2:37-44.

Gerdemann JW, Nicolson TH (1963) Spores of mycorrhizal Endogone species extracted from soil by wet sieving and decanting. Trans Br Mycol Soc 46:235-244.

Gibson DJ, Hetrick BAD (1988) Topographic and fire effects on the composition and abundance of VA-mycorrhizal fungi in tallgrass prairie. Mycol 80:433-441 1988. 
Giovannetti M, Mosse B (1980) An evaluation of techiniques for measuring vesicular arbuscular mycorrhizal infecion in roots. New Phytol 84:489-500.

Haskins KE, Gehring CA (2004) Long-term effects of burning slash on plant communities and arbuscular mycorrhizae in a semi-arid woodland. J Appl Ecol 41:379-388.

He X, Mouratov S, Steinberg Y (2002) Temporal and spatial dynamics of vesicular-arbuscular mycorrhizal fungi under the canopy of Zygophyllum dumosum Boiss in the Negev Desert. J Arid Environ 52:379-387.

Jiménez-Esquilín AE, Stromberger ME, Massman WJ, Frank JM, Shepperd WD (2007) Microbial community structure and activity in a Colorado Rocky Mountain forest soil scarred by slash pile burning. Soil Biol Biochem 39:111-1120.

Kelly RM, Edwards DG, Thompson JG, Magarey RC (2001) Responses of sugarcane, mayze, and soybean to phosphorus and vesicular-arbuscular mycorrhizal fungi. Aust J Agric Res 52:731-743.

Klopatec CC, Debano LF, Klopatec JM (1988) Effects of simulated fire on vesicular-arbuscular mycorrhizae in pinyonjuniper woodland soil. Plant Soil 109:245-249.

Knicker H (2007) How does fire affect the nature and stability of soil organic nitrogen and carbon? A review. Biogeochem 85:91-118.

König S, Wubet T, Dormann CF, Hempel S, Renker C, Busco F (2010) TaqMan real-time PCR assay to assess arbuscular mycorrhizal responses to field manipulation of grassland biodiversity: effects of soil characteristics, plant species richness, and functional traits. Appl Environ Microbiol 76:3765-3775.

Korb JE, Johnson NC, Covington WW (2004) Slash pile burning effects on soil biotic and chemical properties and plant establishment: recommendations for amelioration. Restor Ecol 12:52-62.

Lingfei L, Anna Y, Zhiwei Z (2005) Seasonality of arbuscular mycorrhizal symbiosis and dark septate endophytes in a grassland site in southwest China. FEMS Microbiol Ecol 54:367-373.

Littell RC, Milliken GA, Stroup WW, Wolfinger RD, Schabenberber O (2006) SAS for Mixed Models. 2ed. SAS Institute Inc, Cary, North Carolina, USA.

Macedo IC, Seabra JEA, Silva JEAR (2008) Green house gases emission in the production and use of ethanol from sugarcane in Brazil: the 2005/2006 averages and a prediction for 2020. Biomass Bioenergy 32:582-595.

Machado W, Telles TS, Tavares-Filho J, Guimarães MF, Alves GB, Borges JLB (2010) Physical properties of a Rhodic Haplustox under two sugarcane harvesting systems. Rev Bras Ciênc Solo 34:1803-1809.

Magurran AE (1988) Ecological diversity and its measurement. Princenton University Press, Princeton, USA.

Nasim G, Ali A, Munawar A, Bajwa R (2008) Seasonal dynamics of AM fungi in sugarcane (Saccharum officinarum L. Cv. SPF-213) in relation to red rot (Colletotrichum falcatum) disease from Punjab, Pakistan. Pak J Bot 40:2587-2600.

O'dea ME (2007) Influence of mycotrophy on native and introduced grass regeneration in a semiarid grassland following burning. Restor Ecol 15:149-155.

Otsuka S, Sudiana I, Komori A, Isobe K, Deguchi S, Nishiyama M, Shimizy H, Senoo K (2008) Community structure of soil bacteria in a tropical rain forest several years after fire. Microbes Environ 23:49-56.

Panosso AR, Marques-Jr J, Milori DMBP, Ferraudo AS, Barbieri DM, Pereira GT, La-Scala-Jr N (2011) Soil $\mathrm{CO}_{2}$ emission and its relation to soil properties in sugarcane areas under slash-and-burn and green harvest. Soil Tillage Res 111:190-196.

Raij BV, Andrade JC, Cantarella H, Quaggio JA (2001) Análise química para avaliação da fertilidade de solos tropicais. Instituto Agronômico, Campinas, Brazil.

Redecker D, Schüßler A, Stockinger H, Stürmer SL, Morton JB, Walker C (2013) An evidence-based consensus for the classification of arbuscular mycorrhizal fungi (Glomeromycota). Mycorrhiza 23:515-531.

Reis MR, Tironi SP, Costa MD, Silva MCS, Ferreira EA, Belo AF, Barbosa MHP, Silva AA (2009) Colonização micorrízica e atividade de fosfatases ácidas na rizosfera de cultivares de cana-de-açúcar após aplicação de herbicidas. Planta Daninha 27:977-985.

Reis VM, Paula MA, Döbereiner J (1999) Ocorrência de micorrizas arbusculares e da bactéria diazotrófica Acetobacter diazotrophicus em cana-de-açúcar. Pesqui Agropecu Bras 34:1933-1941.

Resende AS, Xavier RP, Oliveira OC, Urquiaga S, Alves BJR, Boddey RM (2006) Long-term effects of pre-harvest burning and nitrogen and vinasse applications on yield of sugar cane and soil carbon and nitrogen stocks on a plantation in Pernambuco, N.E. Brazil. Plant Soil 281:339-351.

Rillig MC, Mummey DL (2006) Mycorrhizas and soil structure. New Phytol 171:41-53.

Rokni N, Goltapeh ME, Alizadeh A (2010) Some new recorded species of arbuscular mycorrhizal fungi associated with sugarcane crop in Iran. J Agric Technol 6:67-78.

Rumpel C, Alexis M, Chabbi A, Chaplot V, Rasse DP, Valentin C, Mariotti A (2006) Black carbon contribution to soil organic matter composition in tropical soil sloping land user slash and burn agriculture. Geoderma 130:35-46.

Schenck NC, Pérez Y (1990) Manual for identification of VA mycorrhizal fungi. 3 ed. Synergistic, Gainesville, FL.

Shukla A, Kumar A, Jha A, Salunkhe O, Vyas D (2012) Soil moisture levels affect mycorrhization during early stages of development of agroforestry plants. Biol Fertil Soil doi: 10.1007/s00374-012-0744-8.

Silva AS, Inoue H, Endo T, Yano S, Bon EPS (2010) Milling pretreatment of sugarcane bagasse for enzymatic hydrolysis and ethanol fermentation. Bioresour Technol 101:74027409.

Sivakumar N (2012) Effect of edaphic factors and seasonal variation on spore density and root colonization of arbuscular mycorrhizal fungi in sugarcane fields. Ann Microbiol doi:10.1007/s13213-012-0455-2.

Smith SE, Read DJ. (2008) Mycorrhizal Symbiosis 3 ed. Academic Press, New York.

Soccol CR, Vandenberghe LPS, Medeiros ABP, Karo SG, Buckeridge $\mathrm{M}$, Ramos LP, Pitarelo AP, Ferreira-Leitão V, Gottschalk LMF, Ferrara MA, Bon EPS, Moraes LMP, Araújo JA, Torres FAG (2010) Bioethanol from lignocelluloses: status and perspectives in Brazil. Bioresour Technol 101:4820-4825. 
Srikumar R, Murugaian P, Thangaraj R (2009) Survey of arbuscular mycorrhizal fungi-associated with sugarcane in south India. Agric Sci Dig 29:19-22.

Stürmer SL, Siqueira JO, (2008) Diversidade de fungos micorrízicos arbusculares em ecossistemas brasileiros. In: Moreira F.M.S., Siqueira J.O., Brussard L. (eds). Biodiversidade do Solo em Ecossistemas Brasileiros. Editora UFLA, Lavras, p 537-583.

Tominaga TT, Cássaro FAM, Bacchi OOS, Reichardt K, Oliveira JCM, Timm LC (2002) Variability of soil water content and bulk density in a sugarcane field. Aust J Soil Res 40:605614 .
Van Der Heijden MGA, Boller T, Wiemken A, Sanders IR (1998) Different arbuscular mycorrhizal fungi species are potential determinants of plant community structure. Ecol 79:2082-2091.

Vierheilig H, Coughlan AP, Wyss U, Piché Y (1998) Ink and vinegar, a simple staining technique for arbuscular-mycorrhizal fungi. Appl Environ Microbiol 64:5004-5007.

Wilson GWT, Rice CW, Rillig MC, Springer A, Hartnett DC (2009) Soil aggregation and carbon sequestration are tightly correlated with the abundance of arbuscular mycorrhizal fungi: results from long-term field experiments. Ecol Lett 12:452-461.

All the content of the journal, except where otherwise noted, is licensed under a Creative Commons License CC BY-NC. 